\title{
"Theorizing and institutionalizing operation Sukuma Sakhe: a case study of integrated service delivery"
}

$\begin{array}{ll}\text { AUTHORS } & \text { Nonhlanhla Ignatia Ndlovu } \\ \text { Pumela Msweli }\end{array}$

Nonhlanhla Ignatia Ndlovu and Pumela Msweli (2016). Theorizing and

ARTICLE INFO institutionalizing operation Sukuma Sakhe: a case study of integrated service delivery. Environmental Economics, 7(4-1), 161-170. doi:10.21511/ee.07(41).2016.08

DOI http://dx.doi.org/10.21511/ee.07(4-1).2016.08

RELEASED ON Wednesday, 21 December 2016

JOURNAL "Environmental Economics"

FOUNDER LLC "Consulting Publishing Company "Business Perspectives"

NUMBER OF REFERENCES

0
NUMBER OF FIGURES

0

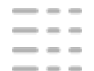

NUMBER OF TABLES

0

(C) The author(s) 2023. This publication is an open access article. 


\title{
Nonhlanhla Ignatia Ndlovu (South Africa), Pumela Msweli (South Africa) \\ Theorizing and institutionalizing operation Sukuma Sakhe: a case study of integrated service delivery
}

\begin{abstract}
The authority of South Africa is in the midst of a profound economic crisis precipitated by high levels of unemployment and inequality, marked by political shifts unprecedented in scope subsequent to the 2016 local government elections. The recent election outcomes reveal disturbances in the social, political and economic systems of the country. These disturbances have been precipitated by low economic growth trajectory and poor investment in service delivery infrastructure. The central thesis of this paper is that in addressing the triple challenge of poverty, inequality and unemployment, a symptomatic approach of addressing social ills and service delivery will not work. This paper draws from institutional theory as a sense-making mechanism to produce a scientific approach to integrated service delivery. Using the tenets of the critical reflecting methodological approach, institutional theory is deconstructed to provide an understanding of how to operationalize integrated service delivery across functions in a scientific fashion.
\end{abstract}

Keywords: service delivery, institutional theory, poverty, inequality and unemployment.

JEL Classification: L8, J64, J71, I32.

\section{Introduction}

The South African government is in the midst of a profound economic crisis precipitated by high levels of unemployment and inequality, marked by political shifts unprecedented in scope subsequent to the 2016 local government elections. The recent election outcomes reveal disturbances in the social, political and economic systems of the country. The disturbance in social and economic systems has been precipitated by high incidences of service delivery protests that gave rise to state assets being put to the torch in Limpopo (Vhuwani, 2016) and in KwaZulu-Natal (Isithebe in Mandeni, 2016). The protest wave in poor urban areas is generally recognized to have started in 2004. Nleya (2011) attributes service delivery failures to unresponsive local councils towards citizens.

Social practices of burning down institutions have been promulgated by individualistic ideologies that do not see beyond the immediate sense of helplessness and even joblessness. Against this hopeless state of affairs, KwaZulu-Natal, the second largest province in South Africa with an estimated population of $11,065,240$, is burdened with the plight of poverty and unemployment. KwaZulu-Natal's (Stats SA, 2016) unemployment rate of $23.2 \%$ in Q1 (2016) increased from 20.5\% in Q4 (Q1 Stats SA QLFS, 2016) and caused a surge of the unemployment rate to $39.3 \%$ for youth (Q1 Stats SA QLFS, 2016). KwaZulu Natal has the 3rd highest poverty measure in SA, with a poverty gap of $25.5 \%$ and poverty severity incidence of $14.4 \%$ (Stats SA, 2016).

(C) Nonhlanhla Ignatia Ndlovu, Pumela Msweli, 2016.

Nonhlanhla Ignatia Ndlovu, Dr., Faculty of Management Sciences, ML Sultan Campus, Durban University of Technology, South Africa.

Pumela Msweli, Ph.D., Professor, Faculty of Management Sciences, Durban University of Technology, South Africa.
The central thesis of this paper is that in addressing the triple challenge of poverty, inequality and unemployment, a symptomatic approach of addressing social ills and service delivery will not work. This paper draws from institutional theory as a sense-making mechanism to produce a scientific approach to integrated service delivery. Using the tenets of the critical reflecting methodological approach, institutional theory will be deconstructed to provide an understanding of how to operationalize integrated service delivery across functions scientifically. Drawing from a number of scholars (see, for example, Borton, 1970; Dewey, 1933; Kolb, 2005; Schön, 1983), the paper "reflectively and reflexively" examines gaps in knowledge, as well as milestones and challenges in institutionalizing operation Sukuma Sakhe. Accordingly, this paper is structured as follows: the first part provides an overview of operation Sukuma Sakhe as a way of operationalizing integrated service delivery. Next, we present the history of the integrated service delivery program (OSS) and how it has been used as a system to eradicate poverty and as an approach to development and growth. We, then, introduce the core constructs of institutional theory using the social context and pressures as a lens against which to critique institutional theory. Next, we discuss how the different dimensions of institutional theory manifest in operation Sukuma Sakhe, how institutionalization OSS has been heightened or diminished. These critiques allow us to identify weaknesses and strengths of the OSS program from the ontological and epistemological perspective of institutional theory. We conclude with a discussion of the implications of the weaknesses and offer a set of recommendations to strengthen operation Sukuma Sakhe. 


\section{An overview of operation Sukuma Sakhe}

1.1. Overview of the program. In response to the triple challenges of poverty, inequality and unemployment (Ngidi et al., 2014, p. 215), the KwaZulu-Natal provincial government introduced an approach known as the flagship program later called operation Sukuma Sakhe, translated as "Stand Up and Build". This came from the motto of the Province, which is: 'Masisukume sakhe'. The approach aimed at integrating, co-ordinating and facilitating the delivery of transversal services to communities (Ndlovu, 2013, p. 1). The other critical areas for Sukuma Sakhe are community partnership, behavior change, economic activities and environmental care. This was to be achieved by creating and maintaining cross-functional teams at provincial, district, local and ward levels to deliver integrated services to individuals, households and communities. The cross-functional teams are made up of officials from national and provincial departments and local government. The main aim was to unify government, civil societies, business sectors and communities to actively participate in building KwaZulu-Natal (Ndlovu, 2013, p. 1).

The introduction of Sukuma Sakhe meant that government had to shift from its traditional and bureaucratic approach of delivering services vertically to citizens and embrace cross-functional teams, consisting of employees from different departments. These teams, working with stakeholders of civil society, business and communities, identify community and household needs within wards, deliver integrated, transversal services monitoring and providing feedback to the communities.

All eleven members of the Provincial Executive Council, known as Cabinet, and their heads of departments lead Sukuma Sakhe. The members of Executive Council and heads of departments are champions of specified district municipalities where they provide leadership. Their role in this is not to deliver a vertical service of their own departmental mandate, but rather to lead a team of all departments and ensure that integrated services are delivered to communities. If there are challenges, these teams interact with the communities to solve the challenges or escalate issues where necessary.

\section{History and how operation Sukuma Sakhe has evolved over time}

In response to the development challenges faced by the province of KwaZulu-Natal, an approach was launched by government in 2009 called the Flagship Program focusing on: fighting diseases, in particular, HIV, AIDS and TB; poverty and promoting food security; empowerment of women and youth and driving an aggressive behavior change against social ills such as teenage pregnancy, gender-based violence, substance abuse, crime and road accidents. The approach is better captured by quoting the former Premier of KwaZulu-Natal, in the State of the Province Address of 2011 (KwaZulu-Natal State of the Province Address, 2011, p. 29) where he said:

"In 2009 the provincial government started a program of integrating all departments and focused on solving community problems on the ground, starting with areas of abject poverty and making a difference".

This approach has been named the Flagship Project, with members of Executive Councils (MECs) acting as district champions. The campaign focused on promoting human values, while simultaneously redressing the ills of the past inequities.

The introduction of the Flagship Program meant that government had to shift the manner it delivers services and prioritize the areas of abject poverty at ward level lowest area of government function. Each ward had to establish a poverty 'war room'. The war room became a term used to describe a government operation office in a local community. The war room consists of people who are community care givers, community volunteers and members of the community that profile the households and bring the needs of the households and the community at large to the war rooms. The war room conducts weekly meetings where issues of the ward are discussed and possible solutions for the challenges proposed. The government, then, provides services on the basis of the recommendations provided by war room structures. The members of the war room from both government and civil society form the war room task team. This task team has officials from different departments who ensure the execution of integrated service delivery.

In 2011, there was evidence that although the flagship program was implemented, there was poor participation by the community members. The flagship was, then, re-launched at the State of the Province Address in 2011, with a new image represented by means of a red ribbon signifying the challenge of HIV, AIDS, TB and social determinants of HIV; and open hands representing all the citizens that are standing up to build the province of KwaZulu-Natal (see Figure 1).

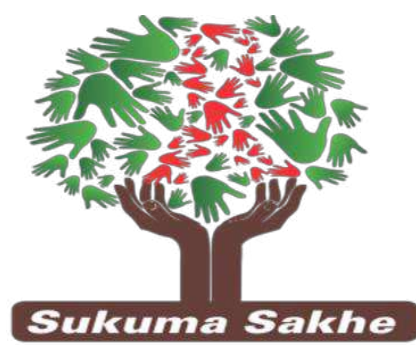

Fig. 1. Sukuma Sakhe symbols and image 
As outlined in the OSS Handbook (2015, p. 12), the program aims to coordinate service delivery by mobilizing community partnerships with private sector, non-governmental organizations, community-based organizations and governmental stakeholders. The integrated service delivery model has four main processes involving (1) household needs identification, (2) appropriate services service identification (3) service delivery and (4) the referral to be closed. Community partnership, behavior change and integrated service delivery are the three principles that underpin successful implementation of the OSS program. Community partnership is the bedrock of OSS because of the vast resources that can be mobilized when communities participate in the design, implementation and monitoring of community-level initiatives. Consequently, service delivery interventions accurately reflect and respond to the real needs at grass root level. Such an approach uses the different knowledge, experiences, needs and capabilities of various groups in the community, involving them from the beginning so that they own the process and become part of the solution.

Behavior change, as explained in the OSS Handbook (2015, p. 18), follows as a result of community partnership. Behavior change is contingent on government taking responsibility of being accountable to the citizens, while citizens take the responsibility of effecting change in their behaviors. OSS also adjusts the behavior of departmental/service provider representatives by changing the way they plan and implement service delivery interventions.

Integrated service delivery, as explained in the OSS Handbook (2015, p. 19), requires government departments, local municipalities, businesses and civil society including all community stakeholders to contribute to service delivery in an integrated manner, through operating within the war rooms. In an attempt to extend the reach of government to communities and to fast track government responses to household and community needs, community fieldworkers, namely, Community Care Givers visit households, where they provide education on health, social services, government services, psychosocial support, and the general conditions of households and these are taken to the war room.

Different support systems have been devised to support communities at ward level. For example, support is offered by Community Development Workers who facilitate interventions together with war room structures. The government facilities in the ward provide support and services to the community via the war room, which is normally closer and central to the community. Another example of support is that given by Extension Officers who provide information and support for food security programs, Sport and Recreation Coordinators who provide support for sport and recreation activities in the ward, driving healthy lifestyles. Social Crime Prevention Volunteers, on the other hand provide information, education and awareness on crime prevention and drug abuse. To promote economic and environmental sustainability, the unemployed are linked to job opportunities and greening projects such as planting trees, fruit, vegetables and medicinal herbs. The beneficiaries for this targeted approach are the children, elderly, sick people, unemployed, unskilled and illiterate, youth, working poor, women, people with disabilities and the poor households.

Once a month, the Members of Executive Council play an oversight role by dedicating a day, called operation Sukuma Sakhe (OSS) Cabinet Day. All members of Executive Council, the Premier and heads of departments as champions are specifically deployed in predetermined wards of the district visited on that particular day. A comprehensive report and action plan are, then, presented to Cabinet by the HOD Champion of that particular district. The report identifies actions that need urgent interventions. Some identified challenges may need a medium to long term approach. The HOD Champion together with OSS structures in the district continuously monitor the implementation of the interventions and feedback is channelled to Cabinet Clusters and finally back to Cabinet.

In addition to engagements on matters of service delivery, OSS Cabinet day affords the Premier and members of the Executive Council (MECs) an opportunity to interact with communities and assess the effectiveness of OSS as an integrated service delivery vehicle. One of the focus areas of OSS Cabinet day is to assess the extent of intervention made in the fight against the HIV and AIDS scourge in the districts.

The Province has the oversight role of mobilizing both government and civil society, through the Provincial Council on AIDS chaired by the Premier, monitoring and evaluating the responses on HIV and TB, including the social determinants of HIV. This includes interventions that emanate from Sukuma Sakhe. Each district and local municipality have the AIDS Councils chaired by Mayors.

After running for seven years, a program review was instituted to assess progress and challenges identified in institutionalizing OSS. It was found 
that 555 out of 828 wards have successfully institutionalized OSS. It was also found that 273 war rooms were either poor, nonfunctional or not established at all. It is on this basis that OSS was adopted as the KwaZulu-Natal intervention to eradicate poverty. The high profile nature of the intervention resulted in a decision being taken to locate the OSS program in the Office of the Premier with the sole purpose of institutionalizing the program to achieve pro-poor growth in the province. The question to ponder upon is what would it take to institutionalize the OSS program across-board? To address this question, institutional theory is deconstructed to identify factors that enable or disable the institutionalization of OSS.

\section{Deconstructing institutional theory}

3.1. Defining institutional theory. Institutional theory is explained by DiMaggio and Powell (1983, p. 148) as the structuration process that consists of four parts: (1) an increase in the extent of interaction among organizations in the field; (2) the emergence of sharply defined inter-organizational structures of domination and patterns of coalition; (3) an increase in the information load with which organizations in a field must contend; and (4) the development of a mutual awareness among participants in a set of organizations that are involved in a common enterprise (DiMaggio, 1982). Kessler (2013, p. 379), on the other hand, views institutional theory as an approach to understanding organizations and management practices as the product of social structures and values rather than economic interests. The appeal of the theory, as explained by Kessler (2013, p. 379), lies in its ability to explain organizational behaviors "that defy economic rationality". Kessler (2013) puts forward a contention that adoption of organizational policies and practices are dependent on social pressures for conformity and legitimacy, rather than technical pressures for economic performance. Kessler's work makes it clear that organizational survival rests on six key concepts that form the basis of institutional theory: (1) infusion of value and meaning beyond functionality; (2) diffusion or adaptation of innovation on the basis that they are in sync with social and community values; (3) rational myths, or prevailing myths about what constitutes economic rationality; (4) loose coupling achieved by separating the formal adoption of a practice from its implementation; (5) legitimacy acquired by adopting isomorphic practices in order to appear to be a legitimate organization; (6) isomorphism or appearing to conform by adopting structures, practices, and behaviors in order to look similar to those organizations that are perceived to be successful.
Earlier scholars of institutional theory (for example, DiMaggio \& Powell, 1991; Garfinkel, 1967) focused their work on the processes of institutionalization using 'rules', 'ceremonial activities' as a process of conforming to an institutional environment (isomorphism). DiMaggio and Powell's (1983) earlier work identified three mechanisms from which institutional isomorphic change occurs: 1) coercive isomorphism emanating from political influence and the challenge of legitimacy; 2) mimetic isomorphism from a standard response to uncertainty; and 3) normative isomorphism, linked to professionalization.

Neoinstitutional theory, as propounded by Kessler (2013), generated a new body of knowledge around "institutional entrepreneurs" who were viewed as having a unique ability to resist the powerful influence of collective social beliefs. Neoinstitutional theorists such as Fernandez-Alles (2006) and Valle-Cabrera and (2006) observed that organizations are socially rewarded by the extent to which they have been legitimized by powerful social actors within the environment they are embedded. Legitimation was viewed as a gateway to accessing resources and ensuring survival.

\section{Core constructs of institutional theory}

4.1. Legitimacy. Legitimacy is defined by FernandezAlles and Valle-Cabrera (2006, p. 507) as a generalized perception or assumption that the actions of an entity are desirable, proper, or appropriate within some socially constructed system of norms, values, beliefs and definitions. Powell \& Colyvas (2008) point out that legitimacy is given meaning by multiple actors in a social environment. Put slightly differently by Kessler (2013), legitimacy is acquired when the company adheres to explicit rules and implicit norms of social environment within which a firm exists.

The legitimation process works on the assumption that (a) an organization builds its structure and processes depending on whom they seek legitimacy from; (2) legitimacy defending strategies differ depending on the audiences that confer legitimacy (Souitaris, Zerbinati \& Liu, 2012). Hwanga and Colyvas (2011, p. 1) citing DiMaggio (1988) further state that the main intellectual agenda guiding studies show how interested actors (directly) shape the emergence of new institutional arrangements. Above and beyond that Hwanga and Colyvas (2011, p. 1) further argue that the current focus on institutional work extends the theoretical and empirical agenda beyond the creation of institutions, to the rest of the life cycle of institutions and brings "actors" to the centre stage of institutional theory, as the principal drivers of institutional change, as well as the stabilizing guardian of institutions. 
4.2. Institutional environment. Meyer and Rowan (1977) view formal structures as myths and ceremony. The authors argue that organizations exist within a social context, in which the rules are not defined by economic activity, they are defined rather by prevailing myths about what constitute economic activity. Therefore, organizations can survive by conforming to or becoming isomorphic with their institutional environment. Meyer and Rowan (1977) observed that organizations will ceremonially adopt practices, and not implement them at functional level. This is done to conform to social pressures.

The process of institutional change is important and Zilber (2002, p. 235) identifies the dialectical interplay between actions (practices and structures), meanings and actors. Pressures that deinstitutionalize organizations whether they are functional, political, or social in nature will not automatically lead to break down of institutionalization, rather those pressures are interpreted, given meaning and responded to by actors.

Through legitimacy, efficiency can be achieved even though this may seem contradictory according to Fernandez-Alles and Valle-Cabrera (2006, p. 507). Therefore, institutional embeddedness encourages development to look at the role of social context in the explanation of heterogeneity, the achievement of efficiency objectives and legitimacy. Granovetter (1985) defines embeddedness as 'economic action within structures of social relations'. Powell (1996) cited by Fernandez-Alles and Valle-Cabrera (2006, p. 507) states that embeddedness overcomes the classic dualities between strategic and institutional substantive, aa well as symbolic, economic and social contexts. Therefore, organizational management and innovation by legitimate organizations are explained as attempts to obtain efficiency and legitimacy provided by stakeholders, whose interests must be taken into account in the management process (Sherer and Lee, 2000).

Conforming to an institutional environment is shown by adopting structures, practices and behaviors similar to leading organizations (Kessler, 2013, p. 381). Therefore, organizations that share the same environment over time will be more similar or isomorphic to each other. This was first articulated by DiMaggio and Powell (1983). In the paper, they identified three types isomorphism, the first being coercive which is more political in nature. The organization wants to appear legitimate to other more powerful actors. This shows how the environment and legitimacy, as discussed above are interlinked. The second type is the need to adopt practices that are assumed to be right to other significant actors. The third type is mimetic and is explained as the copying of other organizations that seem to be more powerful, in order to gain legitimacy. This is common when there is poor clarity.
4.3. Contextual interaction theory. Social structures are also a theme for power dynamics, as they are embedded within social contextual values. FernandezAlles and Valle-Cabrera (2006, p. 508) ascertain that traditionally change had been controversial within the institutionalizm as discussed by Selznick, because it did not accommodate change and adaptation, rather it emphasized inertia and persistence (DiMaggio and Powell, 1991) cited by Fernandez-Alles and ValleCabrera's (2006, p. 508) analyses of adaptation processes. Powell and Colyvas (2008, p. 277) suggest that institutional forces shape individual interest and desires, framing the possibilities for action and influencing whether behaviors result in change or persistence. They contend that actions can either reinforce existing conventions, whilst other actions can reframe or change the conventions.

There are two schools of thought on institutional analysis in respect of individuals, they are either 'cultural dopes' (Garfinkel, 1967, pp. 68-75) or heroic 'change agents' (Strang and Sine, 2002, pp. 503-507). The heroic change agents are those who drive change and cultural dopes are those who are stuck with habits. Although, Powell and Colyvas (2008, p. 277) contend that this is a poor representation of human behavior and institutional analysis, one must also pay attention to everyday processes, as opposed to memorable events, pay attention to less powerful people rather than paying attention to only leaders or champions, pay attention to cultural and cognitive aspects, as well as to the political aspect.

\section{Theorizing and institutionalizing operation Sukuma Sakhe}

A number of scholars who have written on critical reflection (such as Johns, 2010; Johns \& Burnie, 2013; Schön, 1983) point out the importance of reflecting on practice as a mechanism to bring together theory and practice. Reflection, as explained by Paterson and Chapman (2013), involves taking a mindful look at actions, experiences, emotions and responses to interventions to reach a higher level of understanding of a phenomenon under study. In accordance with these views, we present the stages of the lifecycle of operation Sukuma Sakhe. We, then, compare the intended outcome of each stage with the results of the intervention. This process permits a critical reflection of a sequence of events, implemented to heighten the legitimacy of the program. At this point, it is important to highlight the fact that operation Sukuma Sakhe was conceptualized and operationalized by a group of social actors, who were inspired by infusing value beyond functionality. This implies that 'loose coupling' was never going to be a feature in the institutionalization of the program. 
As Figure 2 shows, operation Sukuma Sakhe has been operationalized over a period of seven years, with specific interventions to secure buy-in and to improve the efficiency of the program.
Efficiency is marked by access of services by the indigent citizens at ward level. Figure 2 also depicts the five stages of the program lifecycle.

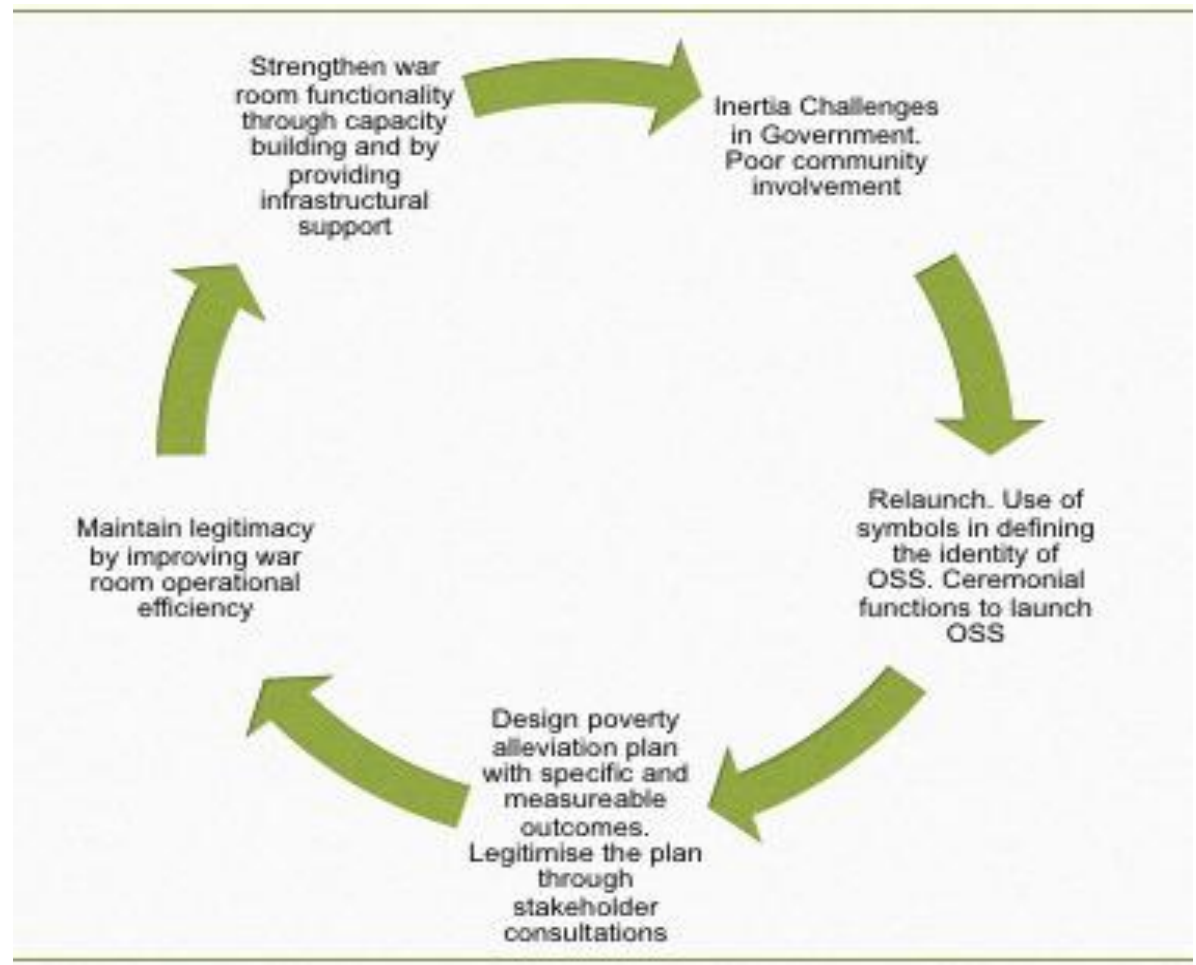

Fig. 2. Five stages of the operation Sukuma Sakhe lifecycle

Table 1. Theorizing and operationalizing the OSS program

\begin{tabular}{|c|c|c|}
\hline OSS lifecycle stage & Institutional theory features in place & Institutional theory features missing \\
\hline Phase 1: Inertia & Inertia & $\begin{array}{l}\text { Institutional entrepreneurs } \\
\text { Social context } \\
\text { Participative competence } \\
\text { Relational context between government and communities } \\
\text { Social values and responsible behavior of citizens }\end{array}$ \\
\hline Phase 2: Inception & $\begin{array}{l}\text { Institutional entrepreneurs } \\
\text { Heroic change agents } \\
\text { Normative isomorphism } \\
\text { Buy in of powerful actors: members of executive council } \\
\text { resolution at a strategic session } \\
\text { Change agents and early adopters: senior managers } \\
\text { across departments at provincial level } \\
\text { Guiding documents, intellectual property } \\
\text { Launching ceremony }\end{array}$ & $\begin{array}{l}\text { Inadequate resources to implement including, infrastructure, human } \\
\text { capital and financial resources; Communication platforms and } \\
\text { technological infrastructure } \\
\text { Deinstitutionalization of policies and practices that entrench inertia } \\
\text { Limited community buy-in } \\
\text { Could neither create nor embed a formidable social structures and } \\
\text { values } \\
\text { Participate competent } \\
\text { Limited legitimacy at government, and at community level } \\
\text { Social values and responsible behavior of citizens }\end{array}$ \\
\hline Phase 3: Inertia & $\begin{array}{l}\text { Loose coupling } \\
\text { Coercive isomorphism } \\
\text { Public face and back-stage reality } \\
\text { Cultural dopes } \\
\text { Could neither create nor embed formidable social } \\
\text { structure and values }\end{array}$ & $\begin{array}{l}\text { Deinstitutionalization of the bureaucratic systems } \\
\text { Could neither create nor embed formidable social structures and } \\
\text { values } \\
\text { Limited social actors with cognitive awareness of their environment } \\
\text { Social context } \\
\text { Social values and responsible behavior of citizens }\end{array}$ \\
\hline Phase 4: Redirect & $\begin{array}{l}\text { Branding with logo, renaming ceremony, renewed } \\
\text { leadership commitment, communication, legitimation, } \\
\text { symbols, infusion of new values. Diffusion }\end{array}$ & $\begin{array}{l}\text { Could neither create nor embed formidable social structures and values } \\
\text { Values } \\
\text { Social context } \\
\text { Limited social actors with cognitive awareness of their environment } \\
\text { Social values and responsible behavior }\end{array}$ \\
\hline Phase 5: Maintainance & $\begin{array}{l}\text { Legitimation through the awards ceremony, training best } \\
\text { practice launched with UNAIDS }\end{array}$ & $\begin{array}{l}\text { Could neither create nor embed formidable social structures and values } \\
\text { Values } \\
\text { Social context } \\
\text { Limited social actors with cognitive awareness of their environment }\end{array}$ \\
\hline
\end{tabular}




\section{Recommendations}

There is a wide range of institutional theory features that have not been in place when operation Sukuma Sakhe was institutionalized. Perhaps the largest institutional theory gap identified in the implementation of OSS is the absence of the social context and values required to confer legitimacy to the OSS program. The elements that fall under the social environment are the values underpinning the sustainability of the program. Not only does the social context limit the institutionalization of OSS, but also its absence diminishes the chances of having social actors with cognitive awareness of their environment. The importance of deinstitutionalizing bureaucratic structures, as envisaged by Kessler (2013), cannot be underestimated. The initial position of inertia will prevail irrespective of the amount of resources, social actors and support in place, if disabling bureaucratic values and structures is not dismantled. Limited support from key actors, insufficient numbers of heroic change agencies at government and at community level that understand the contextual environment, who know how to act and confer legitimacy to operation Sukuma Sakhe have limited the effectiveness of the OSS program. In order to eliminate institutional theory gaps and enhance the capacity of OSS to effectively address the issues of poverty, inequality and employability at ward level it is recommended that:

- The key influencers who are part of what institutional theory refer to as powerful constituencies in the form of political leaders, traditional leaders and general civil society and community leaders become the agents of change by espousing the values of nation building articulated in the Masisukume Sakhe Motto.

- Without leadership fully embracing the OSS program by participating actively in war rooms the program will not reach its full potential.

- Capacity building programs should be designed and rolled out for all the social actors and powerful constituents that confer legitimacy to OSS.

- The leadership should be empowered through capacity building to gain OSS participative competence.
- Each provincial department should craft an OSS policy that creates an enabling environment for institutionalizing the program inter and intradepartmentally.

- Performance contracts at provincial, district municipality and local municipality levels should incorporate indicators related to the OSS program.

- Constant support and recognition should be given to heroic actors who are change agents, who resist the bureaucratic environment and legitimize Sukuma Sakhe within government.

- Constant support and recognition should be given to the heroic actors in communities who resist the current inertia at community level and are driving Sukuma Sakhe.

- Increase the diffusion of innovation by communicating this new approach of Sukuma Sakhe as a sustainable and new way of doing business in KZN.

- Redraft Batho Pele principles to incorporate OSS values and principles.

- Develop a communication campaign that leverages on different communication platforms including print, electronic and social media connecting all citizens and harnessing their energy towards strengthening OSS.

- Budgeting processes at provincial, district municipality and local municipality levels must support the OSS program.

- An OSS Public and Private Forum must be established to draw in professionals and the private sector to support the OSS program.

- Increase the number and capacity of community field workers who support the OSS program.

- Develop research capacity for data mining to feed into decision-making processes to enhance OSS.

- Develop tools, indicators and research instruments to track poverty.

- Government functions both in technical and institutional environment. Therefore, the functional and technical structures should be aligned to deliver on the OSS program.

- Develop a body of knowledge around OSS to inform institutional memory, basic education, and the tertiary education sector.

- Develop a standardized National Curriculum to train civil servants, and the tertiary education sector in integrated service delivery with an inservice training component.

\section{References}

1. Amenta, E. and Ramsey, K. (2010). Institutional Theory. In Leicht, K.T. and Jenkins, J.C. eds., The Handbook of Politics: State and Civil Society in Global Perspective. New York: Springer, pp. 15-40.

2. Battilana, J., Leca, B. and Boxenbaum, E. (2009). How Actors Change Institutions: Towards a Theory of Institutional Entrepreneurship, The Academy of Management Annals, 3(1), pp. 65-107. 
3. Dacin, M.T., Goodstein, J. and Scott. (2002). Insitutional Theory and institutional change Introduction to the special reaserch forum, Academy of Management Journal, 45(1), pp. 45-57.

4. DiMaggio, P.J. and Powell. (1983). The Iron Cage Revisited: Institutional Isomorphism and Collective Rationality in Organizational Fields, American Sociological Review, 48(2), pp. 147-160.

5. American Sociological Association. Available at http://www.jstor.org/stable/2095101 (Accessed: 04 July 2016)

6. Fernandez, S. and Rainey, H.G. (2006). Managing successful organizational change in the public sector, Public Administration Review, 66(2), pp. 168-176. Available at: http://eds.a.ebscohost.com/eds/detail/detail ?sid=f2699dc4-a65f-4733-aef0-2007. Accessed on 20 July 2016.

7. Fernández-Alles, M. and Valle-Cabrera, R. (2006). Reconciling institutional theory with organizational theories, Journal of Organizational Change Management, 19(4), pp. 503-517. Available at: http://dx.doi.org/10.1108/09534810610676699. Accessed on 23 June 2016.

8. Heugens, P.P., M.A.R. and Lander, M.W. (2009). Structure! Agency! Structure! (and other Quarrels): A MetaAnalysis of Institutional Theories of Organization, Academy of Management Journal, 52(1), pp. 61-85. Available at: http://amj.aom.org/content/52/1/61.short. Accessed on: 18 June 2016.

9. Hwang, H. and Colyvas, J.A. (2011). Problematizing Actors and Institutions in Institutional Work, Journal of Management Inquiry, 20, March 2011, pp. 62-66 Available at: http://jmi.sagepub.com/content/20/1/62. Accessed on 24 June 2016).

10. Jensen, J.L. (2003). Policy Diffusion through Institutional Legitimation: State Lotteries, Journal of Public Administration Research and Theory: J-PART, 13(4), Oct. 2003, pp. 521-541. Available at: http://www.jstor.org.dutlib.dut.ac.za/stable/3525660?pqorigsite=summon\&seq=1\#page_scan_tab_contents.

Accessed on 28 June 2016)

11. Kessler, E.H. (2013). Encyclopedia of Management Theory, Thousand Oaks, California: SAGE Publications, Inc. Available at: http://search.ebscohost.com/login.aspx?direct=true \&db=nlebk\&AN=592558\&site=ehost-live. Accessed on 01 July 2016.

12. Selznick, P. (1949). TVA and the grass roots: A study in the sociology of formal organization. Berkeley: University of California Press.

13. Meyer, J.W. and Rowan, B. (2007). Institutionalized Organizations : Formal Structure as Myth and Ceremony, American Journal of Sociology, 83(2), Sep. 1977, pp. 340-363. The University of Chicago Press. Available at http://www.jstor.org/stable/2778293. (Retrieved on 17 July 2016).

14. Msweli-Mbanga, P. and Mkhize, H. (2007). The Risk - Adjusted Performance of Companies with Female Directors: a South African Case, SAJEMS, 10(2), pp. 207-213.

15. Ndlovu, N.I. (2013) Organizational change factors that impact on implementation of Sukuma Sakhe in KwaZulu Natal. Dissertation submitted in partial fulfilment of masters degree in business administration.

16. Ngidi, N.V.E., Kuzwayo, B.F., Ndlovu, N.I, Moonlall, R., Mkhize, S.F., Ngwenya, T.N and Behari, N. (2013). Operation Sukuma Sakhe and the Social development Perspective. Social Work in an International Perspective: History, views, diversity and human rights. Ed. De Kock, C, Van Kerckhove, C. and Vens, E.

17. Nleya, N. (2011). Linking service delivery and protest in South Africa: an exploration of evidence from Khayelitsha, Africanus, 50(1), pp. 3-13

18. Operation Sukuma Sakhe. Operations handbook. (2015). Available at: kznonline.gov.za. Accessed on 07 September 2016.

19. O'toole, L.J.O. (2004). The Theory-Practice Issue in Policy Implementation Research, Public Administration, 82(2), pp. 309-329. Blackwell Publishing Ltd/Inc. Available at: http://onlinelibrary.wiley.com/doi/10.1111/j.00333298.2004.00396.x/full. Accessed on 06 August 2016.

20. Powell, W.W. and Colyvas, J.A. (2008). Microfoundations of institutional theory, The SAGE Handbook of Organizational Institutionalizm. Available at: http://sarpn.org/documents/e0000006/Poverty_Inequality_SA.pdf. Accessed on 28 June 2016.

21. Provincial Growth and Development Plan. (2012). KwaZulu Natal Planning Commission. Available at: www. KZNonline.gov.za

22. Souitaris, V., Zerbinati, S. and Liu, G. (2012). Which Iron Cage? Endo- and exo-isomorphism in Corporate Venture Capital Programs, The Academy of Management Journal, 55(2), April 2012. Available at: https://www.researchgate.net/publication/263329316. Accessed on 06 August 2016.

23. State of the KwaZulu Natal Province Address. (2011). Available at: http://www.kznonline.gov.za/images/stories/ downloads/SOPA/sopa\%202011.pdf. Accessed on 05 July 2016.

24. Statistics South Africa. (2014). The South African MPI. Report No. 03-10-08. Pretoria: Office of the Statistician General. Available at: http://www.statssa.gov.za/publications/Report-03-10-08/Report-03-10-082014.pdf. Accessed on 23 July 2016.

25. Statistics South Africa. (2015). 2015 KwaZulu Natal Customer Satisfaction Survey Analytical Report. Pretoria. Available at: http://www.statssa.gov.za/publications/Report-03-00-07/Report-03-00-072015.pdf. Accessed on 15 July 2016.

26. Statistics South Africa. (2015). Millennium Development Goals: Country report 2015, Pretoria. Available at: www.statssa.gov.za/MDG/MDG_Country\%20Report_Final30Sep2015.pdf. Accessed on 15 July 2016. 
27. Strang, D. and Sine, W.D. (2002). Interorganizational institutions, Journal Companion to organizations, pp. 497519. Blackwel.

28. Zilber, T.M. (2002). Institutionalization as an Interplay between Actions, Meanings, and Actors: The Case of a Rape Crisis Center in Israel, Academy of Management Journal, 45(1), pp. 234-254. Accessed on: .

29. Zucker, G.L. (1977). The Role of Institutionalization in Cultural Persistence, American Sociological Review, 42(5), Oct. 1977, pp. 726-743. American Sociological Association. Available at: http://www.jstor.org/ stable/2094862on. Accessed on 07 September 2016. 